\title{
Bench-top Root-zone Heating Hastens Development of Petunia under a Lower Air Temperature
}

\author{
Madeline W. Olberg and Roberto G. Lopez ${ }^{1,2}$ \\ Department of Horticulture and Landscape Architecture, Purdue University, \\ 625 Agriculture Mall Drive, West Lafayette, IN 47907
}

Additional index words. cold-tolerant species, bedding plant production, bottom heating, Petunia $\times$ hybrida, mean daily temperature

\begin{abstract}
Heating accounts for up to $30 \%$ of total operating costs for greenhouse operations in northern latitudes. Growers often lower air temperatures for production to reduce energy costs; however, this causes delays in development even in cold-tolerant crops, such as petunia (Petunia $\times$ hybrida). This delay increases production time and can reduce profitability. Recent studies on low air temperature bedding plant production indicate petunia as a strong potential candidate for using lower air temperatures in combination with bench-top root-zone heating $(\mathrm{RZH})$ to avoid or reduce delays in development. The objectives of this study were to 1) quantify time to flower (TTF) of seven petunia cultivars and two recombinant inbred lines (RILs) when the mean daily air temperature (MDT) was lowered by $5^{\circ} \mathrm{C}$ and bench-top RZH was used and 2) determine if a high-quality petunia crop can be produced on RZH. Petunia 'Sun Spun Burgundy', 'Sun Spun Lavender Star', 'Sanguna Patio Red', 'Potunia Plus Red', 'Potunia Plus Purple', 'Supertunia Red', 'Supertunia Bordeaux', and two RILs, IA160 and IA349, were grown in a greenhouse with an MDT of $15^{\circ} \mathrm{C}$ without $\mathrm{RZH}$ or with a $R Z H$ set point of 21, 24, or $27^{\circ} \mathrm{C}$. Additionally, a commercial control (CC) was established by growing plants without RZH at an MDT of $20^{\circ} \mathrm{C}$. All plants were grown under a 16-hour photoperiod to provide a daily light integral (DLI) of $\approx 12 \mathrm{~mol} \cdot \mathrm{m}^{-2} \cdot \mathrm{d}^{-1}$. Time to flower was shorter at higher RZH set points. For example, TTF of 'Potunia Plus Red' was 56, 52, 49, or 47 days for plants grown at an MDT of $15^{\circ} \mathrm{C}$ without $\mathrm{RZH}$, or with $\mathrm{RZH}$ set points of 21,24 , or $27^{\circ} \mathrm{C}$, respectively. When a RZH set point of $27^{\circ} \mathrm{C}$ was employed, TTF of all cultivars and inbred lines, except 'Potunia Plus Red' and 'Sanguna Patio Red', was similar to plants grown in the CC. Shorter stem length, lower growth index, and smaller shoot dry mass (SDM) at flowering were observed for plants grown under lower air temperatures with RZH, resulting in a more compact and high-quality plant. Producing a compact plant in a shorter time period is beneficial for growers; thus, results suggest that MDT can be lowered to $15^{\circ} \mathrm{C}$ for petunia production when a RZH set point of $27^{\circ} \mathrm{C}$ is employed.
\end{abstract}

Greenhouse heating currently accounts for up to $30 \%$ of total operating costs for growers in northern latitudes, which is subject to increase with increasing energy costs for fuels such as propane and heating oil (Lopez and Runkle, 2014). Growers are therefore continually seeking ways to produce

Received for publication 24 May 2016. Accepted for publication 25 Aug. 2016.

We gratefully acknowledge Lopez lab members, Rob Eddy for greenhouse and laboratory assistance; Judy Santini for statistical assistance; Ryan Warner for seeds of recombinant inbred lines; Ball Horticultural Company, Dümmen-Orange, Proven Winners, and Syngenta Flowers for cuttings; Everris NA, Inc. for fertilizer; and SunGro Horticulture for substrate. We also thank C. Raker \& Sons, Inc. for rooting cuttings and seed germination.

The use of trade names in this publication does not imply endorsement by Purdue University or Michigan State University of products named or criticism of similar ones not mentioned.

${ }^{1}$ Current address: Department of Horticulture, Michigan State University, 1066 Bogue Street, East Lansing, MI 48824

${ }^{2}$ Corresponding author. E-mail: rglopez@msu.edu. high-quality bedding plants through late winter and early spring with reduced energy inputs for heating, by installing thermal energy curtains, purchasing more efficient heaters or boilers, increasing insulation, or lowering air temperature set points for production (Brumfield, 2007; Runkle and Both, 2011). When MDT set points are lowered, flowering is often delayed (Blanchard and Runkle, 2011). Although growers correlate lower air temperatures to energy cost savings, these delays can often increase production costs, or lead to missed market dates (Blanchard et al., 2011b). Recent studies investigating the effects of low temperature production in greenhouses and high tunnels indicate that flowering of cold-tolerant crops, such as petunia (Petunia $\times$ hybrida), is delayed by 19 to $32 \mathrm{~d}$ when air temperature is lowered by 9 to $12{ }^{\circ} \mathrm{C}$ (Blanchard et al., 2011a, 2011b; Currey et al., 2014; Gerovac et al., 2015). However, Gerovac (2014) reported that the flowering of seed propagated petunia 'Dreams Midnight' was only delayed by $4 \mathrm{~d}$ when grown at an MDT of $16{ }^{\circ} \mathrm{C}$ in combination with bench-top RZH of $27{ }^{\circ} \mathrm{C}$ compared with an MDT of $19{ }^{\circ} \mathrm{C}$ without RZH.

Petunias are one of the most prominent and popular bedding plants sold in the United States. Total wholesale value of this crop was over $\$ 262$ million in 2014 , with $\approx 25$ million potted petunias sold in the top 15 producing states (USDA, 2015a, 2015b). Petunia has a reported optimum temperature $\left(T_{\text {opt }}\right)$ of $\approx 25{ }^{\circ} \mathrm{C}$, where the rate of development is most rapid, and a calculated base temperature $\left(T_{\mathrm{b}}\right)$ of $1.5{ }^{\circ} \mathrm{C}$, where development ceases (Kaczperski et al., 1991; Warner, 2010). Plants are generally categorized based on $T_{\mathrm{b}}$ as cold tolerant, cold intermediate, or cold sensitive, when $T_{\mathrm{b}} \leq 4{ }^{\circ} \mathrm{C}, 4^{\circ} \mathrm{C}<T_{\mathrm{b}}<7{ }^{\circ} \mathrm{C}$, or $T_{\mathrm{b}} \geq 7{ }^{\circ} \mathrm{C}$, respectively (Blanchard and Runkle, 2011). A linear increase in the rate of plant development is generally observed in the range between $T_{\mathrm{b}}$ and $T_{\mathrm{opt}}$ (Adams et al., 1998). Growers therefore select temperature set points within this range and adjust for desired market dates and finished plant quality. Although growing at the $T_{\text {opt }}$ may produce a crop most rapidly, a decrease in plant quality is often observed (Blanchard et al., $2011 \mathrm{~b}$ ). Overall, as MDT increases, rate of crop development increases, up to the $T_{\text {opt }}$.

Adams et al. (1998) reported that, under natural photoperiods, petunia 'Express Blush Pink' grown at 22 or $25{ }^{\circ} \mathrm{C}$ flowered $43 \mathrm{~d}$ faster than when grown at $15{ }^{\circ} \mathrm{C}$. Similarly, Blanchard et al. (2011b) found that under a 16-h photoperiod, TTF of petunia 'Dreams Neon Rose' was hastened by $19 \mathrm{~d}$ as the MDT increased from 14 to $26{ }^{\circ} \mathrm{C}$. Petunias are long-day plants; therefore, the rate of development is also hastened by increasing photoperiod up to a critical photoperiod of $14.4 \pm$ $0.6 \mathrm{~h} \cdot \mathrm{d}^{-1}$, although this can vary by cultivar (Adams et al., 1998).

Root-zone heating has been found to be an efficient method of increasing the rate of development for a variety of crops, including verbena (Verbena $\times$ hybrida), petunia, poinsettia (Euphorbia pulcherrima), chrysanthemum (Dendranthema $\times$ grandiflorum), tomato (Solanum lycopersicum), african violet (Saintpaulia ionantha), and snapdragon (Antirrhinum majus) (Brown and Ormrod, 1980; Gerovac, 2014; Janes et al., 1981; McAvoy and Janes, 1984; Olberg and Lopez, 2016; Vogelezang, 1988; Wai and Newman, 1992). For example, Gerovac (2014) reported that verbena 'Aztec Blue Velvet' took $18 \mathrm{~d}$ longer to flower in an MDT of $16{ }^{\circ} \mathrm{C}$ when grown without RZH, compared with when grown on a RZH set point of $27^{\circ} \mathrm{C}$. Benchtop RZH functions by circulating hot water through a series of rubber tubes on top of the bench. Potted crops are then placed into trays directly on the rubber tubes, allowing heat to transfer to the substrate, root system, and plant via conduction, and into the canopy by convection as heat rises from the bench, creating a microclimate with the plant canopy (Sachs et al., 1992; Vogelezang, 1988; Vogelezang and van Weel, 1989).

The effect of MDT on petunia has been extensively studied, but to our knowledge, there has been little research on the effect of 
increased root-zone temperature in combination with a lower air temperature on petunia cultivars and inbred lines. Commercially available, vegetatively propagated petunia cultivars were all selected based on breeder input for cold tolerance and vigorous growth. The objectives of this study were therefore to 1) quantify TTF of seven petunia cultivars and two RILs when the MDT was lowered by $5{ }^{\circ} \mathrm{C}$ and bench-top RZH was used and 2) determine if a high-quality petunia crop could be produced on RZH. Petunias, like most bedding plants, are considered high quality, when they are compact, fill the container, well branched, and in flower.

\section{Materials and Methods}

Plant material and culture. Rooted cuttings of petunia 'Sun Spun Burgundy', 'Sun Spun Lavender Star', 'Sanguna Patio Red', 'Potunia Plus Red', 'Potunia Plus Purple', 'Supertunia Red', and 'Supertunia Bordeaux' and seedlings of two RILs derived from the interspecific cross Petunia integrifolia $\times \mathrm{Pe}$ tunia axillaris, IA160 and IA349, were received at Purdue University, West Lafayette, IN (lat. $40^{\circ} \mathrm{N}$ ) between 13 and 20 Jan. 2015 (week 2 or 3 ). The RILs were selected based on exhibiting: 1) a relatively high development rate under cool $\left(14{ }^{\circ} \mathrm{C}\right)$ temperature, and 2) a minimal reduction in development rate as temperature decreased from 20 to $14{ }^{\circ} \mathrm{C}$, from among the total population of $\approx 150$ RILs evaluated previously (Lin, 2014). The apical meristem of each 'Sun Spun Burgundy', 'Sun Spun Lavender Star', 'Sanguna Patio Red', 'Potunia Plus Red', and 'Potunia Plus Purple' plant was excised on 19 Jan. 2015. The apical meristem of each 'Supertunia Red' and 'Supertunia Bordeaux' plant was excised on 20 Jan. 2015. On 20 Jan. 2015, ethephon (Florel; Monterey, Fresno, CA) with a surfactant $\left(0.4 \mathrm{~mL} \cdot \mathrm{L}^{-1}\right)$ (Capsil; Aquatrols, Paulsboro, NJ) was applied as a foliar spray, at a concentration of $400 \mathrm{mg} \cdot \mathrm{L}^{-1}$ and a volume of $0.2 \mathrm{~L} \cdot \mathrm{m}^{-2}$, to abort and abscise all premature flowers and flower buds. All plants were transplanted on 21 Jan. 2015 into 11.4-cm $(600 \mathrm{~mL})$ containers filled with soilless substrate consisting of (by volume) $65 \%$ peat, $20 \%$ perlite, and $15 \%$ vermiculite (Fafard 2 Mix; SunGro Horticulture, Agawam, MA).

Irrigation water was supplemented with 93\% sulfuric acid (Brenntag, Reading, PA) at $0.08 \mathrm{~mL} \cdot \mathrm{L}^{-1}$ to reduce alkalinity to 100 $\mathrm{mg} \cdot \mathrm{L}^{-1}$ and maintain a $\mathrm{pH}$ within the range of 5.8 to 6.2. All plants were fertigated once per week with acidified water supplemented with a combination of two water-soluble fertilizers $(3: 1$ mixture of $15 \mathrm{~N}-2.2 \mathrm{P}-12.5 \mathrm{~K}$ and $21 \mathrm{~N}-2.2 \mathrm{P}-16.6 \mathrm{~K}$, respectively; Everris, Marysville, $\mathrm{OH}$ ) to provide the following (in $\mathrm{mg} \cdot \mathrm{L}^{-1}$ ): $400 \mathrm{~N}, 52 \mathrm{P}, 326 \mathrm{~K}, 100 \mathrm{Ca}, 40 \mathrm{Mg}$, 2.0 Fe, $1.0 \mathrm{Mn}$ and $\mathrm{Zn}, 0.48 \mathrm{Cu}$ and $\mathrm{B}$, and 0.2 Mo. All plants were overhead irrigated with clear acidified water as necessary, based on observation and weight of multiple pots within each treatment and block, between fertigation events to maintain similar substrate moisture and nutrition levels among all treatments.

Greenhouse environment. Plants were grown in two separate glass-glazed greenhouses. In both greenhouses, a 16-h photoperiod (0600 to $2200 \mathrm{HR}$ ) was established consisting of natural daylengths with day extension and supplemental lighting provided by high-pressure sodium lamps that delivered $70 \mu \mathrm{mol} \cdot \mathrm{m}^{-2} \cdot \mathrm{s}^{-1}$ to achieve a DLI of $\approx 12 \mathrm{~mol} \cdot \mathrm{m}^{-2} \cdot \mathrm{d}^{-1}$. A computerized control program (Maximizer Precision 10; Priva Computers Inc., Vineland Station, ON, Canada) monitored, controlled, and recorded greenhouse air temperature. Greenhouse air temperature was regulated by use of evaporative cooling pads and exhaust fans, hot water radiant heating, and retractable shade curtains.

Temperature treatments were initiated on 22 Jan. 2015. The air temperature set point was $15{ }^{\circ} \mathrm{C}$ and plants were placed onto benches with or without independently programmable bench-top RZH. Root-zone temperatures of 21,24 , and $27{ }^{\circ} \mathrm{C}$ were established with circulating hot water $\left(49^{\circ} \mathrm{C}\right)$ though rubber tubing on the benches, controlled by a root-zone thermistor probe inserted horizontally at the center of the substrate (Biotherm Benchwarmer kit; TrueLeaf Technologies, Petaluma, CA). A separate greenhouse served as a $\mathrm{CC}$ and had a set point of $20{ }^{\circ} \mathrm{C}$ without RZH.

Environmental data collection. Throughout the study, air temperature was measured every $10 \mathrm{~min}$ by an aspirated Priva temperature sensor and recorded by the computerized control system (Priva Computers Inc.) in each greenhouse. An enclosed thermistor (Model ST-100; Apogee Instruments, Inc., Logan, UT) inserted horizontally into the center of the substrate was used to measure substrate temperature. A fine-wire thermistor (Model ST-200; Apogee Instruments, Inc.) was inserted into the apical meristem of one plant per treatment and block on 5 Feb. to measure plant tissue temperature. A thermistor (Model ST-110) surrounded by an aspirated radiation shield suspended at plant canopy level measured canopy air temperature. Single-diode quantum sensors (Model LI-190R; LI-COR, Inc., Lincoln, NE) were placed at canopy level to record photosynthetic photon flux $(P P F)$ in each treatment and block. For each treatment and block, substrate, plant tissue, and canopy air temperatures and $P P F$ were measured every $15 \mathrm{~s}$, averaged, and logged every $15 \mathrm{~min}$ by a data logger (Model CR1000; Campbell Scientific, Inc., Logan, UT). Mean greenhouse air, canopy, substrate, and plant tissue temperature and DLI for each treatment, each month following transplant, are reported in Table 1.

Plant data collection and calculations. Plants were monitored daily and the date of first open flower was recorded when the first flower was fully reflexed. At flowering, node number below the first open flower and stem length, measured from the base of the plant to the apical meristem, were recorded. Branch number was also recorded for petunia IA160,
IA349, 'Supertunia Red', and 'Supertunia Bordeaux'; and plant width and perpendicular width were recorded for petunia 'Sun Spun Burgundy', 'Sun Spun Lavender Star', 'Sanguna Patio Red', 'Potunia Plus Red', and 'Potunia Plus Purple'. Growth index [GI; $\mathrm{GI}=($ stem length + plant width + plant perpendicular width)/3] was then calculated for petunia 'Sun Spun Burgundy', 'Sun Spun Lavender Star', 'Sanguna Patio Red', 'Potunia Plus Red', and 'Potunia Plus Purple'. Branch number was recorded for plants with prostrate growth and branching from the base node, while GI was calculated for all plants with upright or mounding growth habit. Roots of 'Sun Spun Lavender Star', 'Supertunia Bordeaux', 'Potunia Plus Purple', and IA349 were soaked, gently washed, and excised and shoots of all cultivars and RILs were excised. Roots and shoots were dried separately in an oven at $70{ }^{\circ} \mathrm{C}$. After $4 \mathrm{~d}$ of drying, roots and shoots were weighed to determine root dry mass (RDM) and SDM, respectively. Time to flower was calculated as days from transplant (21 Jan.) to first open flower. Root-to-shoot ratio (RDM:SDM) was calculated for 'Sun Spun Lavender Star', 'Supertunia Bordeaux', 'Potunia Plus Purple', and IA349.

Experimental design and data analysis. The experiment was a complete randomized design, with two blocks of each RZH treatment. Ten experimental units (single plants of each cultivar or RIL) were randomly distributed to each treatment within each block. Cultivars and RILs were analyzed independently. A separate greenhouse served as the CC and was maintained at a commercial finishing temperature with two blocks, each containing ten experimental units. Analysis of variance was performed using the SAS (SAS 9.4; SAS Institute Inc., Cary, NC) mixed-model (PROC MIXED) procedure. Fisher's protected least significant difference was used to compare the four RZH treatments at $P<0.05$. Blocks were pooled when the treatment by block interaction was not significant or when trends of treatment responses were consistent. A $t$ test was used to compare $\mathrm{RZH}$ treatment means to the $\mathrm{CC}$ mean.

\section{Results and Discussion}

Effects of $R Z H$ on rate of flowering. Time to flower was hastened with higher RZH set points for most cultivars and RILs grown under a lower air temperature (Table 2). For example, TTF of 'Supertunia Bordeaux' was $49,43,41$, or $39 \mathrm{~d}$ for plants grown at an MDT of $15^{\circ} \mathrm{C}$ without RZH, or with RZH set points of 21,24 , or $27^{\circ} \mathrm{C}$, respectively. With the exception of 'Potunia Plus Red' and 'Sanguna Patio Red', all plants grown at an MDT of $15^{\circ} \mathrm{C}$ with a RZH set point of $27^{\circ} \mathrm{C}$ had similar or quicker TTF compared with plants grown at an MDT of $20^{\circ} \mathrm{C}$. Time to flower of 'Sun Spun Lavender Star' was $4.4 \mathrm{~d}$ shorter for plants grown on a RZH set point of $27^{\circ} \mathrm{C}$ and MDT of $15^{\circ} \mathrm{C}$, compared with the CC. Flowering of all cultivars and RILs 
Table 1. Mean daily light integral (DLI) and daily air, canopy, substrate, and plant tissue temperature for each treatment, each month following transplant. Plants were grown at a mean daily temperature (MDT) of $15^{\circ} \mathrm{C}$ and plants were placed on a bench without root-zone heating (No RZH) or with RZH set points of 21,24 , or $27^{\circ} \mathrm{C}$; or plants were grown in a greenhouse without RZH at an MDT of $20^{\circ} \mathrm{C}$ as per commercial control (CC).

\begin{tabular}{|c|c|c|c|c|c|c|}
\hline \multirow[b]{2}{*}{ Month } & \multirow[b]{2}{*}{ Treatment } & \multirow[b]{2}{*}{ Avg DLI $\left(\mathrm{mol} \cdot \mathrm{m}^{-2} \cdot \mathrm{d}^{-1}\right)$} & \multicolumn{4}{|c|}{ Temperature $\left({ }^{\circ} \mathrm{C}\right)$} \\
\hline & & & Air & Canopy & Substrate & Tissue \\
\hline \multirow[t]{5}{*}{ January } & No RZH & 13.0 & $15.9^{\mathrm{z}}$ & 15.6 & 16.2 & $-{ }^{y}$ \\
\hline & $21{ }^{\circ} \mathrm{C} \mathrm{RZH}$ & 11.1 & & 17.1 & 20.5 & - \\
\hline & $24^{\circ} \mathrm{C} \mathrm{RZH}$ & 11.7 & & 17.2 & 23.1 & - \\
\hline & $27{ }^{\circ} \mathrm{C} \mathrm{RZH}$ & 13.4 & & 17.9 & 25.2 & - \\
\hline & $\mathrm{CC}$ & 11.0 & 19.5 & 18.9 & 18.6 & - \\
\hline \multirow[t]{5}{*}{ February } & No RZH & 14.5 & 14.9 & 14.4 & 15.3 & 14.5 \\
\hline & $21{ }^{\circ} \mathrm{C} \mathrm{RZH}$ & 13.4 & & 16.6 & 21.4 & 15.2 \\
\hline & $24{ }^{\circ} \mathrm{C} \mathrm{RZH}$ & 13.2 & & 17.0 & 23.3 & 15.7 \\
\hline & $27{ }^{\circ} \mathrm{C} \mathrm{RZH}$ & 14.8 & & 17.1 & 24.9 & 16.5 \\
\hline & $\mathrm{CC}$ & 13.0 & 19.2 & 18.7 & 17.8 & 16.2 \\
\hline \multirow[t]{5}{*}{ March } & No RZH & 14.8 & 15.3 & 14.9 & 15.6 & 15.7 \\
\hline & $21{ }^{\circ} \mathrm{C} \mathrm{RZH}$ & 15.3 & & 16.2 & 21.2 & 15.9 \\
\hline & $24{ }^{\circ} \mathrm{C} \mathrm{RZH}$ & 15.1 & & 17.2 & 23.2 & 16.8 \\
\hline & $27{ }^{\circ} \mathrm{C} \mathrm{RZH}$ & 14.9 & & 17.4 & 24.2 & 19.7 \\
\hline & $\mathrm{CC}$ & 14.8 & 19.2 & 18.7 & 17.4 & 16.5 \\
\hline
\end{tabular}

${ }^{\mathrm{z}}$ This air temperature is for all RZH treatments.

${ }^{\mathrm{y}}$ Fine-wire thermistor inserted on $5 \mathrm{Feb}$.

was delayed by an average of $10.7 \mathrm{~d}$ when grown at an MDT of $15^{\circ} \mathrm{C}$ without RZH, compared with those grown at an MDT of $20{ }^{\circ} \mathrm{C}$ (Fig. 1).

Gerovac (2014) reported a linear decrease in TTF for the seed propagated petunia 'Dreams Midnight' with increased RZH from 18 to $27^{\circ} \mathrm{C}$. For example, TTF was 5,10 , or $12 \mathrm{~d}$ shorter for plants grown at an MDT of $16{ }^{\circ} \mathrm{C}$ with a RZH set point of 21,24 , or $27{ }^{\circ} \mathrm{C}$, respectively, compared with without RZH (Gerovac, 2014). Similarly, an accelerated rate of flowering with increased root-zone temperature has been reported for poinsettia, chrysanthemum, peace lily (Spathiphyllum sp.), african violet, and tomato (Brown and Ormrod, 1980; Janes et al., 1981; Vogelezang, 1988, 1992; Wulster and Janes, 1984). For example, TTF of chrysanthemum 'Improved Mefo' was 84 and $99 \mathrm{~d}$ when plants were grown at a day/night temperature of $16 / 11^{\circ} \mathrm{C}$ with RZH of $25^{\circ} \mathrm{C}$ or without $\mathrm{RZH}$, respectively (Brown and Ormrod, 1980).

Similar to the findings of the current study, an acceleration in flowering rate of petunia is frequently reported with increasing air temperatures (Adams et al., 1998; Blanchard and Runkle, 2011; Blanchard et al., 2011a, 2011b; Kaczperski et al., 1991; Warner, 2010; Vaid and Runkle, 2013). For example, TTF of petunia 'Snow Cloud' was 74,56 , or $46 \mathrm{~d}$ when grown at a constant air temperature of 15,20 , or $25^{\circ} \mathrm{C}$, respectively (Kaczperski et al., 1991). Vaid and Runkle (2013) used a linear model to describe the rate of petunia flowering in response to increasing MDT from 14 to $26^{\circ} \mathrm{C}$. Within this model, flowering rate of petunia 'Bravo Blue' increased as temperature increased (Vaid and Runkle, 2013). Blanchard and Runkle (2011) reported a nonlinear response to temperature for petunia 'Dreams Neon Rose' and 'Wave Purple' with increasing MDT from 5 to $30^{\circ} \mathrm{C}$; plants did not reach $T_{\text {opt }}$ within this range, but $T_{\mathrm{b}}$ was calculated to be 2.8 and $5.5^{\circ} \mathrm{C}$ for petunia 'Dreams
Neon Rose' and 'Wave Purple', respectively. Petunia can therefore be categorized as cold tolerant or cold intermediate, depending on cultivar.

Rate of development is directly influenced by plant temperature, and increased tissue temperature was measured with increased RZH. For example, plant tissue temperature was an average of 15.1, 15.6, 16.3 , and $18.1^{\circ} \mathrm{C}$ for plants grown at an MDT of $15{ }^{\circ} \mathrm{C}$ without $\mathrm{RZH}$, or with a RZH set point of 21,24 , or $27{ }^{\circ} \mathrm{C}$, respectively (Table 1). Plant tissue temperature of petunias grown at a lower air temperature in combination with RZH of $27{ }^{\circ} \mathrm{C}$ was an average of $1.7{ }^{\circ} \mathrm{C}$ higher than those in the CC. A similar trend of increased tissue temperature with increased RZH has been observed for osteospermum (Osteospermum ecklonis), poinsettia, african violet, and begonia (Begonia ×hiemalis) (Gerovac, 2014; Olberg and Lopez, 2016; Vogelezang, 1988; Vogelezang and van Weel, 1989). Vogelezang (1988) also reported that plant tissue temperature was more closely related to root-zone temperature than greenhouse air temperature. Elevated plant tissue temperature could explain why a similar, shorter, or longer TTF by only up to $4 \mathrm{~d}$ was observed for most petunia plants grown in a greenhouse where the MDT was $5^{\circ} \mathrm{C}$ lower when a RZH set point of $27{ }^{\circ} \mathrm{C}$ was employed, compared with the CC.

Effect of RZH on dry mass accumulation. When harvested at first open flower, SDM of all plants grown at an MDT of $15{ }^{\circ} \mathrm{C}$ was higher for plants grown without RZH compared with those grown with RZH. With the exception of RIL IA349, all plants grown on RZH had similar SDM regardless of RZH set point. For example, SDM of 'Potunia Plus Red' was $5.1,4.8$, and $4.7 \mathrm{~g}$ when grown on $\mathrm{RZH}$ set points of 21,24 , or $27{ }^{\circ} \mathrm{C}$, respectively (Table 2). Conversely, SDM of IA349 was 3 g less with a RZH set point of $27{ }^{\circ} \mathrm{C}$ compared with $21{ }^{\circ} \mathrm{C}$. Shoot dry mass of 'Supertunia Bordeaux', 'Potunia Plus
Purple', 'Supertunia Red', 'Sun Spun Lavender Star', and IA349 grown at an MDT of $20^{\circ} \mathrm{C}$ was similar to plants grown at an MDT of $15^{\circ} \mathrm{C}$ with a RZH set point of 24 or $27{ }^{\circ} \mathrm{C}$. Although, all 'Sun Spun Burgundy', 'Potunia Plus Red', IA160, and 'Sanguna Patio Red' plants had a greater SDM when grown at a lower air temperature, regardless of RZH, compared with the CC.

Similar to other studies, biomass accumulation was reduced when rate of development increased (Brown and Ormrod, 1980; Gerovac, 2014; Shedlosky and White, 1987). This resulted in a lower SDM for plants grown at a lower air temperature with RZH compared with without RZH. Dry mass accumulation is a direct result of photosynthesis, and is therefore directly related to both net photosynthesis and time for photosynthate production, and thus production time (Heins et al., 2000). In the current study, as flowering of 'Supertunia Red' was hastened by $13 \mathrm{~d}$, SDM decreased from 9.2 to $5.2 \mathrm{~g}$, for plants with no RZH compared with a RZH set points of $27{ }^{\circ} \mathrm{C}$. Since plants grown without RZH took longer to flower, they had a longer production time and therefore more time to increase biomass before harvest at flowering. Similar TTF thus resulted in similar SDM. For example, TTF and SDM of 'Potunia Plus Purple' was 40.2, 40.2, or $42.1 \mathrm{~d}$ and 3.1, 3.0, or $2.9 \mathrm{~g}$ for plants grown at an MDT of $15^{\circ} \mathrm{C}$ with a RZH set point of 24 or $27{ }^{\circ} \mathrm{C}$ or at an MDT of $20{ }^{\circ} \mathrm{C}$ without RZH, respectively. Gerovac (2014) similarly reported an about linear decrease of TTF and SDM with increasing RZH for petunia and snapdragon. Likewise, final dry mass of pansy (Viola $\times$ wittrockiana 'Imperial Blue') and petunia 'White Cascade' grown with RZH set points of 16 to $21^{\circ} \mathrm{C}$ and a night temperature of $7{ }^{\circ} \mathrm{C}$ had similar dry mass to plants grown without $\mathrm{RZH}$ and a night temperature of $16{ }^{\circ} \mathrm{C}$ (Shedlosky and White, 1987).

When harvested at first open flower, RDM was an average of 22 to $52 \%$ greater for plants grown at an MDT of $15^{\circ} \mathrm{C}$, regardless of RZH, compared with those grown at an MDT of $20{ }^{\circ} \mathrm{C}$ (data not shown). Similarly, $\mathrm{RDM}$ was $\approx 60 \%$ lower for snapdragon plants grown at an MDT of $16{ }^{\circ} \mathrm{C}$, regardless of RZH from 18 to $27{ }^{\circ} \mathrm{C}$, compared with those grown at an MDT of $19^{\circ} \mathrm{C}$ (Gerovac, 2014). For plants grown without RZH, increased production time due to higher TTF could have caused this increase in RDM. Root-zone heating may also have stimulated increased root growth, as McMichael and Burke (1998) reported an increase in root growth with increasing $\mathrm{RZH}$ to a species-specific $T_{\text {opt }}$. Although increasing temperatures of $\mathrm{RZH}$ did not show any significant effects on RDM in the current study (data not shown), increased root growth was apparent for some cultivars grown with RZH (Fig. 1).

Root-to-shoot ratio was higher for 'Potunia Plus Purple' and IA349 plants grown at an MDT of $15^{\circ} \mathrm{C}$ with a RZH set point of $27^{\circ} \mathrm{C}$, compared with those plants grown without RZH (Table 2). Root-to-shoot ratio was higher when plants were grown at a lower 
Table 2. Growth index (GI), branch number, stem length, shoot dry mass (SDM), root-to-shoot ratio, and time to flower (TTF) for petunia 'Sun Spun Lavender Star', 'Sun Spun Burgundy', 'Supertunia Red', 'Supertunia Bordeaux', 'Potunia Plus Red', 'Potunia Plus Purple', 'Sanguna Patio Red', and two inbred lines IA160 and IA349. Plants were grown at a mean daily temperature (MDT) of $15^{\circ} \mathrm{C}$ and plants were placed on a bench without root-zone heating (No RZH) or with RZH set points of 21, 24, or $27{ }^{\circ} \mathrm{C}$; or plants were grown in a greenhouse without RZH at an MDT of $20^{\circ} \mathrm{C}$ as per commercial control (CC).

\begin{tabular}{|c|c|c|c|c|c|c|}
\hline Treatment & GI & Branch number & Stem length $(\mathrm{cm})$ & SDM $(g)$ & Root-to-shoot ratio & TTF (d) \\
\hline \multicolumn{7}{|c|}{ 'Sun Spun Lavender Star’ } \\
\hline No RZH & $16.0 \mathrm{ab}^{\mathrm{z}}$ & $--^{\mathrm{y}}$ & $11.1 \mathrm{a}$ & $5.0^{\mathrm{x}} \mathrm{a}$ & 0.05 & $46.5^{\mathrm{x}} \mathrm{a}$ \\
\hline $21{ }^{\circ} \mathrm{C} \mathrm{RZH}$ & $14.5^{\mathrm{x}} \mathrm{ab}$ & - & $10.1^{\mathrm{x}} \mathrm{ab}$ & $3.4^{\mathrm{x}} \mathrm{b}$ & $0.06^{\mathrm{x}}$ & $40.1 \mathrm{bc}$ \\
\hline $24^{\circ} \mathrm{C}$ RZH & $16.9 \mathrm{a}$ & - & $10.6^{\mathrm{x}} \mathrm{a}$ & $3.9 \mathrm{ab}$ & $0.05^{\mathrm{x}}$ & $43.4 \mathrm{ab}$ \\
\hline $27^{\circ} \mathrm{C}$ RZH & $13.8^{\mathrm{x}} \mathrm{b}$ & - & $9.4^{\mathrm{x}} \mathrm{b}$ & $3.3^{\mathrm{x}} \mathrm{b}$ & $0.07^{\mathrm{x}}$ & $37.6^{\mathrm{x}} \mathrm{c}$ \\
\hline $\mathrm{CC}$ & 16.6 & - & 11.2 & 4.0 & 0.04 & 42.0 \\
\hline Significance $^{\mathrm{w}}$ & * & & $* *$ & $* *$ & NS & $* * *$ \\
\hline \multicolumn{7}{|c|}{ 'Sun Spun Burgundy’ } \\
\hline No RZH & $15.8^{\mathrm{x}}$ & - & $10.3 \mathrm{ab}$ & $5.5^{\mathrm{x}} \mathrm{a}$ & - & $55.4^{\mathrm{x}} \mathrm{a}$ \\
\hline $21{ }^{\circ} \mathrm{C}$ RZH & $15.8^{\mathrm{x}}$ & - & $10.5 \mathrm{a}$ & $4.6^{\mathrm{x}} \mathrm{b}$ & - & $52.6^{\mathrm{x}} \mathrm{a}$ \\
\hline $24^{\circ} \mathrm{C}$ RZH & 15.2 & - & $10.0 \mathrm{ab}$ & $4.8^{\mathrm{x}} \mathrm{ab}$ & - & $52.6^{\mathrm{x}} \mathrm{a}$ \\
\hline $27^{\circ} \mathrm{C}$ RZH & 14.9 & - & $9.7 \mathrm{~b}$ & $4.7^{\mathrm{x}} \mathrm{b}$ & - & $48.1 \mathrm{~b}$ \\
\hline $\mathrm{CC}$ & 14.7 & - & 10.0 & 4 & - & 49.2 \\
\hline Significance & * & & $*$ & $* *$ & & $* * *$ \\
\hline \multicolumn{7}{|c|}{ 'Supertunia Red' } \\
\hline No RZH & - & $10.8^{\mathrm{x}} \mathrm{a}$ & $17.2^{\mathrm{x}} \mathrm{a}$ & $9.2^{\mathrm{x}} \mathrm{a}$ & - & $52.7^{\mathrm{x}} \mathrm{a}$ \\
\hline $21{ }^{\circ} \mathrm{C} \mathrm{RZH}$ & - & $8.8^{\mathrm{x}} \mathrm{ab}$ & $16.3^{\mathrm{x}} \mathrm{ab}$ & $6.5^{\mathrm{x}} \mathrm{b}$ & - & $45.4^{\mathrm{x}} \mathrm{b}$ \\
\hline $24^{\circ} \mathrm{C}$ RZH & - & $11.1^{\mathrm{x}} \mathrm{ab}$ & $15.2^{\mathrm{x}} \mathrm{b}$ & $6.9^{\mathrm{x}} \mathrm{b}$ & - & $46.1^{x} b$ \\
\hline $27^{\circ} \mathrm{C}$ RZH & - & $10.4^{\mathrm{x}} \mathrm{b}$ & $13.1 \mathrm{c}$ & $5.2 \mathrm{~b}$ & - & $39.7 \mathrm{c}$ \\
\hline $\mathrm{CC}$ & - & 9.3 & 13.4 & 4.5 & - & 40.4 \\
\hline Significance & & * & $* * *$ & $* * *$ & & $* * *$ \\
\hline \multicolumn{7}{|c|}{ 'Supertunia Bordeaux' } \\
\hline No RZH & - & $10.2^{\mathrm{x}}$ & $18.3^{\mathrm{x}} \mathrm{a}$ & $7.5^{\mathrm{x}} \mathrm{a}$ & $0.09^{\mathrm{x}}$ & $49.4^{\mathrm{x}} \mathrm{a}$ \\
\hline $21{ }^{\circ} \mathrm{C} \mathrm{RZH}$ & - & $9.3^{x}$ & $16.0 \mathrm{ab}$ & $5.1^{\mathrm{x}} \mathrm{b}$ & $0.16^{x}$ & $42.8^{\mathrm{x}} \mathrm{b}$ \\
\hline $24^{\circ} \mathrm{C}$ RZH & - & $9.9^{\mathrm{x}}$ & $15.3 \mathrm{~b}$ & $4.5 \mathrm{~b}$ & $0.24^{\mathrm{x}}$ & $41.3 \mathrm{bc}$ \\
\hline $27^{\circ} \mathrm{C} \mathrm{RZH}$ & - & $8.9^{\mathrm{x}}$ & $14.5^{\mathrm{x}} \mathrm{b}$ & $4.3 \mathrm{~b}$ & $0.21^{\mathrm{x}}$ & $38.9 \mathrm{c}$ \\
\hline $\mathrm{CC}$ & - & 8.0 & 15.7 & 4.4 & 0.12 & 40.3 \\
\hline Significance & & NS & $* *$ & $* * *$ & NS & $* * *$ \\
\hline \multicolumn{7}{|c|}{ 'Potunia Plus Red' } \\
\hline No RZH & $18.1^{\mathrm{x}} \mathrm{a}$ & - & $12.6^{\mathrm{x}} \mathrm{a}$ & $6.3^{\mathrm{x}} \mathrm{a}$ & - & $55.8^{\mathrm{x}} \mathrm{a}$ \\
\hline $21{ }^{\circ} \mathrm{C}$ RZH & $17.5^{\mathrm{x}} \mathrm{ab}$ & - & $11.8^{\mathrm{x}} \mathrm{ab}$ & $5.1^{\mathrm{x}} \mathrm{b}$ & - & $51.8^{\mathrm{x}} \mathrm{b}$ \\
\hline $24^{\circ} \mathrm{C} \mathrm{RZH}$ & $16.8 \mathrm{~b}$ & - & $11.5 \mathrm{~b}$ & $4.8^{\mathrm{x}} \mathrm{b}$ & - & $48.7^{x} c$ \\
\hline $27^{\circ} \mathrm{C} \mathrm{RZH}$ & $16.3 \mathrm{~b}$ & - & $11.0 \mathrm{~b}$ & $4.7^{x} b$ & - & $47.2^{\mathrm{x}} \mathrm{c}$ \\
\hline $\mathrm{CC}$ & 16.3 & - & 11.3 & 3.7 & - & 44.2 \\
\hline Significance & $* *$ & & $* * *$ & $* * *$ & & $* * *$ \\
\hline \multicolumn{7}{|c|}{ 'Potunia Plus Purple' } \\
\hline No RZH & $14.6 \mathrm{a}$ & - & $8.7 \mathrm{a}$ & $4.0^{\mathrm{x}} \mathrm{a}$ & $0.08 \mathrm{~b}$ & $48.8^{\mathrm{x}} \mathrm{a}$ \\
\hline $21^{\circ} \mathrm{C}$ RZH & $14.2 \mathrm{ab}$ & - & $8.2 \mathrm{ab}$ & $3.3^{\mathrm{x}} \mathrm{b}$ & $0.10 \mathrm{ab}$ & $43.3 \mathrm{~b}$ \\
\hline $24^{\circ} \mathrm{C} \mathrm{RZH}$ & $13.4^{\mathrm{x}} \mathrm{b}$ & - & $7.6^{x} b$ & $3.1 \mathrm{~b}$ & $0.12 \mathrm{ab}$ & $40.2 \mathrm{~b}$ \\
\hline $27^{\circ} \mathrm{C}$ RZH & $13.3^{x} b$ & - & $7.7^{x} b$ & $3.0 \mathrm{~b}$ & $0.21^{\mathrm{x}} \mathrm{a}$ & $40.2 \mathrm{~b}$ \\
\hline $\mathrm{CC}$ & 14.2 & - & 8.3 & 2.9 & 0.08 & 42.1 \\
\hline Significance & $* *$ & & $* * *$ & $* * *$ & * & $* * *$ \\
\hline \multicolumn{7}{|c|}{ 'Sanguna Patio Red' } \\
\hline No RZH & $16.4^{\mathrm{x}}$ & - & 9.5 & $5.6^{\mathrm{x}} \mathrm{a}$ & - & $52.8^{\mathrm{x}} \mathrm{a}$ \\
\hline $21{ }^{\circ} \mathrm{C} \mathrm{RZH}$ & 16.0 & - & 9.1 & $4.2^{\mathrm{x}} \mathrm{b}$ & - & $47.9^{\mathrm{x}} \mathrm{bc}$ \\
\hline $24^{\circ} \mathrm{C} \mathrm{RZH}$ & 16.0 & - & 8.9 & $4.9^{\mathrm{x}} \mathrm{ab}$ & - & $49.1^{\mathrm{x}} \mathrm{ab}$ \\
\hline $27^{\circ} \mathrm{C} \mathrm{RZH}$ & 15.6 & - & 9.0 & $4.4^{\mathrm{x}} \mathrm{b}$ & - & $44.5^{\mathrm{x}} \mathrm{c}$ \\
\hline $\mathrm{CC}$ & 15.2 & - & 9.0 & 2.6 & - & 40.0 \\
\hline Significance & NS & & NS & $* * *$ & & $* * *$ \\
\hline \multicolumn{7}{|c|}{ IA160 } \\
\hline No RZH & - & $15.0^{\mathrm{x}} \mathrm{a}$ & $27.9^{\mathrm{x}} \mathrm{a}$ & $19.6^{\mathrm{x}} \mathrm{a}$ & - & $66.3^{\mathrm{x}} \mathrm{a}$ \\
\hline $21{ }^{\circ} \mathrm{C}$ RZH & - & $12.9^{\mathrm{x}} \mathrm{b}$ & $25.1^{\mathrm{x}} \mathrm{b}$ & $11.3^{\mathrm{x}} \mathrm{b}$ & - & $56.9^{x} b$ \\
\hline $24^{\circ} \mathrm{C}$ RZH & - & $12.6^{\mathrm{x}} \mathrm{b}$ & $24.5 \mathrm{bc}$ & $11.9^{x} b$ & - & $56.7^{x} b$ \\
\hline $27^{\circ} \mathrm{C}$ RZH & - & $11.7 \mathrm{~b}$ & $22.6 \mathrm{c}$ & $11.1^{\mathrm{x}} \mathrm{b}$ & - & $51.4 \mathrm{c}$ \\
\hline $\mathrm{CC}$ & - & 11.6 & 23.4 & 10.2 & - & 50.4 \\
\hline \multirow[t]{2}{*}{ Significance } & & $* * *$ & $* * *$ & $* * *$ & & $* * *$ \\
\hline & & & IA349 & & & \\
\hline No RZH & - & $19.1^{\mathrm{x}} \mathrm{a}$ & $28.2^{\mathrm{x}} \mathrm{a}$ & $22.8^{\mathrm{x}} \mathrm{a}$ & $0.05^{\mathrm{x}} \mathrm{c}$ & $68.2^{\mathrm{x}} \mathrm{a}$ \\
\hline $21{ }^{\circ} \mathrm{C} \mathrm{RZH}$ & - & $16.0^{\mathrm{x}} \mathrm{b}$ & $24.6^{x} b$ & $12.2^{\mathrm{x}} \mathrm{b}$ & $0.07^{\mathrm{x}} \mathrm{bc}$ & $55.6^{x} b$ \\
\hline $24^{\circ} \mathrm{C} \mathrm{RZH}$ & - & $15.4 \mathrm{~b}$ & $21.9 \mathrm{bc}$ & $10.4 \mathrm{bc}$ & $0.08^{\mathrm{x}} \mathrm{ab}$ & $54.0^{\mathrm{x}} \mathrm{b}$ \\
\hline $27^{\circ} \mathrm{C}$ RZH & - & $14.7^{x} b$ & $19.7 \mathrm{c}$ & $9.2^{\mathrm{x}} \mathrm{c}$ & $0.10^{\mathrm{x}} \mathrm{a}$ & $50.5 \mathrm{c}$ \\
\hline $\mathrm{CC}$ & - & 15.3 & 20.8 & 10.4 & 0.07 & 51.0 \\
\hline Significance & & $* * *$ & $* * *$ & $* * *$ & $* * *$ & $* * *$ \\
\hline
\end{tabular}

${ }^{2}$ Means within column per cultivar with the same letter are not significantly different based on Fisher's protected least significant difference (LSD) at $P \leq 0.05$.

y Data not collected.

${ }^{\mathrm{x}}$ Significant difference from the CC based on LSD at $P \leq 0.05$.

wSignificance of ANOVA comparing RZH treatments.

Ns, ${ }^{*},{ }^{* *},{ }^{* * *}$ Nonsignificant or significant at $P \leq 0.05,0.01$, or 0.001 , respectively. air temperature with a RZH set point of $27{ }^{\circ} \mathrm{C}$, compared with those in the CC. Root-to-shoot ratio of 'Potunia Plus Purple' and IA349 was higher with higher RZH set points. High root-to-shoot ratios with increased RZH are likely due to decreased SDM given hastened flowering and increased $\mathrm{RDM}$ due to root growth promotion with elevated root-zone temperature.

Effects of RZH on plant growth and morphology. When measured at first open flower, stem length was shorter for cultivars and RILs, other than 'Sanguna Patio Red', grown on a RZH set point of $27^{\circ} \mathrm{C}$ compared with those without RZH (Table 2). For example, stem length was 4.1, 5.3, and $8.5 \mathrm{~cm}$ shorter for 'Supertunia Red', IA160, and IA349, respectively, grown at an MDT of $15{ }^{\circ} \mathrm{C}$ with a $\mathrm{RZH}$ set point of $27{ }^{\circ} \mathrm{C}$ compared with without RZH. Stem length of 'Supertunia Red', 'Supertunia Bordeaux', 'Potunia Plus Red', IA160, and IA349 plants grown at an MDT of $15^{\circ} \mathrm{C}$ was greater than plants grown at an MDT of $20^{\circ} \mathrm{C}$. Although, this difference was smaller when plants were grown with a RZH set point of $27{ }^{\circ} \mathrm{C}$. For example, stem length of 'Supertunia Red' was $17.2,16.3,15.2,13.1$, or $13.4 \mathrm{~cm}$ for plants grown at an MDT of $15^{\circ} \mathrm{C}$ without RZH or on a RZH set points of 21,24 , or $27{ }^{\circ} \mathrm{C}$, or at an MDT of $20{ }^{\circ} \mathrm{C}$, respectively (Table 2). Gerovac (2014) reported a similar trend, as stem length of petunia 'Dreams Midnight' was shorter for plants grown at an MDT of $19{ }^{\circ} \mathrm{C}$ compared with MDT of $16^{\circ} \mathrm{C}$; but stem length was similar for plants grown at an MDT of $19{ }^{\circ} \mathrm{C}$ and at an MDT of $16{ }^{\circ} \mathrm{C}$ with a RZH set point of $27{ }^{\circ} \mathrm{C}$. Similarly, a decrease in plant height was reported with increasing RZH from 17 to $29{ }^{\circ} \mathrm{C}$ for chrysanthemum 'May Shoesmith' plants grown in day/night air temperatures of 24/17 ${ }^{\circ} \mathrm{C}$ (McAvoy and Janes, 1984). Conversely, other crops, such as snapdragon and sweet pepper (Capsicum annuum), have been reported to have longer stem length with increasing RZH (Abdel-Mawgoud et al., 2005; Hood and Mills, 1994). This dissimilarity is likely due to high air temperature, rather than lower air temperature, in combination with RZH.

This trend of less growth with the highest RZH set point was consistent for GI for all cultivars, other than 'Sun Spun Burgundy' and 'Sanguna Patio Red'. For example, GI of 'Potunia Plus Red' was 18.2, 17.5, 16.8, 16.3, and $16.3 \mathrm{~cm}$ for plants grown at an MDT of $15{ }^{\circ} \mathrm{C}$ without $\mathrm{RZH}$ or with a RZH set point of 21,24 , or $27^{\circ} \mathrm{C}$, or at an MDT of $20^{\circ} \mathrm{C}$. Similarly, $\approx 25 \%$ less growth was reported for poinsettia 'Annette Hegg Brilliant Diamond' grown with a RZH set point of $29^{\circ} \mathrm{C}$ compared with those grown with a RZH set point of $23{ }^{\circ} \mathrm{C}$ (Janes and McAvoy, 1983). Growth index of 'Sun Spun Burgundy', 'Potunia Plus Red', and 'Sanguna Patio Red' was also smaller for plants grown at an MDT of $20^{\circ} \mathrm{C}$ compared with an MDT of $15{ }^{\circ} \mathrm{C}$ without RZH. Less growth, in terms of stem length and GI, with increased RZH or MDT is likely again due to a decreased TTF 


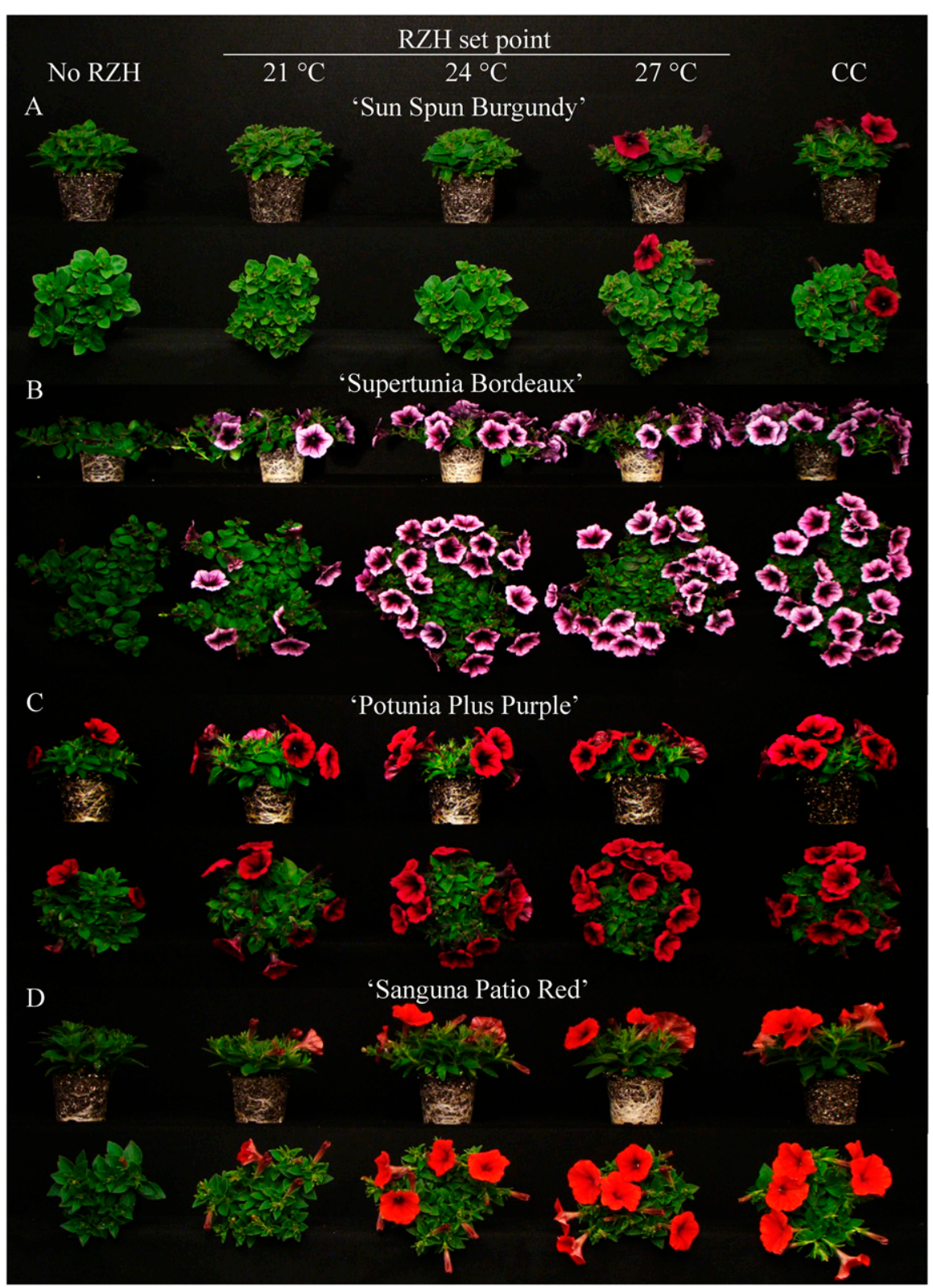

Fig. 1. Petunia (A) 'Sun Spun Burgundy', (B) 'Supertunia Bordeaux', (C) 'Potunia Plus Purple', and (D) 'Sanguna Patio Red' 7 weeks after transplant. Plants were grown at a mean daily temperature (MDT) of $15^{\circ} \mathrm{C}$ and plants were placed on a bench without root-zone heating (No RZH) or with RZH set points of 21,24 , or $27^{\circ} \mathrm{C}$; or plants were grown in a greenhouse without RZH at an MDT of $20^{\circ} \mathrm{C}$ as a commercial control (CC).

and, consequently, a shorter time period for vegetative growth.

When measured at first open flower, branch number of 'Supertunia Red', IA160, and IA349 was higher for plants grown at an MDT of $15{ }^{\circ} \mathrm{C}$ without RZH compared with those on RZH. Branch number and GI were higher for all plants grown at an MDT of $15{ }^{\circ} \mathrm{C}$ compared with an MDT of $20{ }^{\circ} \mathrm{C}$. Overall, plants had less growth with higher root-zone and air temperatures. Root-zone temperature did not significantly affect node number for most plants, though node number was generally lower for plants grown at an MDT of $15{ }^{\circ} \mathrm{C}$ compared with an MDT of $20{ }^{\circ} \mathrm{C}$ (data not shown). This could be due to a more rapid rate of development and thus with RZH, compared with those without. Shoot dry mass of most plants grown at a lower air temperature was similar to the $\mathrm{CC}$ when RZH of 24 to $27^{\circ} \mathrm{C}$ was employed. Stem length of all cultivars and RILs, other than 'Sanguna Patio Red', was shorter with higher RZH set points, resulting in more compact plants.

The shorter production time that results from hastened flowering can directly relate to increased savings for greenhouse operations, especially at a lower air temperature set point. Previous studies reported potential energy savings of $8 \%$ to $15 \%$ by lowering greenhouse air temperature by $3{ }^{\circ} \mathrm{C}$, although results varied based on greenhouse location and market date (Gerovac, 2014). Savings can also result from reduced requirement for greenhouse heating, as the plants occupy the greenhouse for a shorter period of time, or increased number of production turnovers. A smaller overall plant size, as a function of shorter stem length, smaller GI, and lower SDM, was observed for plants grown at a lower air temperature with RZH. Although these differences were slight for some cultivars, compact growth is considered beneficial to growers as a compact plant size allows for fewer plant growth regulator applications, occupies less greenhouse bench space for production, and allows for an increased number of plants per cart for shipping. Given the cultivar specificity of $T_{\mathrm{b}}$, careful crop selection for vigorous and cold-tolerant cultivars may be of great importance for production under this heating regime. Overall, results suggest that a high-quality, compact petunia crop can be produced at an MDT of $15{ }^{\circ} \mathrm{C}$, when combined with a RZH set point of $27^{\circ} \mathrm{C}$.

\section{Literature Cited}

Abdel-Mawgoud, A.M.R., Y.N. Sassine, U.A. ElBehairy, A.F. Abou-Hadid, and S.O. El-Abd. 2005. Effect of minimum root-zone temperature on the growth and production of greenhouse sweet pepper. J. Appl. Sci. Res. 1:72-76.

Adams, S.R., P. Hadley, and S. Pearson. 1998. The effects of temperature, photoperiod, and photosynthetic photon flux on the time to flowering of petunia 'Express Blush Pink'. J. Amer. Soc. Hort. Sci. 123:577-580.

Blanchard, M.G. and E.S. Runkle. 2011. The influence of day and night temperature fluctuations on growth and flowering of annual bedding plants and greenhouse heating cost predictions. HortScience 46:599-603.

Blanchard, M.G., E.S. Runkle, and J.M. Frantz. 2011a. Energy-efficient greenhouse production of Petunia and Tagetes by manipulation of temperature and photosynthetic daily light integral. Acta Hort. 893:857-864.

Blanchard, M.G., E.S. Runkle, and P.R. Fisher. 2011b. Modeling plant morphology and development of petunia in response to temperature and photosynthetic daily light integral. Sci. Hort. 129:313-320.

Brown, W. and D. Ormrod. 1980. Response of the chrysanthemum to soil heating. Sci. Hort. 13: 67-75.

Brumfield, R.G. 2007. Dealing with rising energy costs. Greenhouse Prod. News 17:24-31. 
Currey, C.J., R.G. Lopez, and N.S. Mattson. 2014. Finishing bedding plants: A comparison of an unheated high tunnel versus a heated greenhouse in two geographic locations. HortTechnology 24:527-534.

Gerovac, J.R. 2014. Using energy-efficient technologies to produce bedding plants and microgreens in protected and controlled environments. MS Thesis, Purdue Univ., West Lafayette, IN. Abstr. 1584900.

Gerovac, J.R., R.G. Lopez, and N.S. Mattson. 2015. High tunnel versus climate-controlled greenhouse: Transplant time and production environment impact growth and morphology of cold-tolerant bedding plants. HortScience 50:830-838.

Heins, R.D., B. Liu, and E.S. Runkle. 2000. Regulation of crop growth and development based on environmental factors. Acta Hort. 511:15-24.

Hood, T.M. and H.A. Mills. 1994. Root-zone temperature affects nutrient uptake and growth of snapdragon. J. Plant Nutr. 17:279-291.

Janes, H. and R. McAvoy. 1983. Deleterious effects of cool air temperature reversed by root zone warming in poinsettia. HortScience 18: 363-364.

Janes, H., R. McAvoy, M. Maletta, J. Simpkins, and D. Mears. 1981. The effect of warm root zone temperatures on growth of tomato and poinsettia. Acta Hort. 115:245-258.

Kaczperski, M.P., M.G. Carlson, and M.G. Karlsson. 1991. Growth and development of Petunia $\times$ hybrids as a function of temperature and irradiance. J. Amer. Soc. Hort. Sci. 116:232237.

Lin, W.-K. 2014. Understanding the genetics of development rate in petunia. MS Thesis, Michigan State Univ., East Lansing, MI. Abstr. 1554317.

Lopez, R.G. and E.S. Runkle. 2014. Growing your crops above their base temperature. Greenhouse Grower 32:53-55.

McAvoy, R. and H. Janes. 1984. The effect of root zone heating in conjunction with standard and cool night conditions on the growth of chrysanthemums. Acta Hort. 148:843-851.

McMichael, B.L. and J.J. Burke. 1998. Soil temperature and root growth. HortScience 33:947-951.

Olberg, M.W. and R.G. Lopez. 2016. Growth and development of poinsettia (Euphorbia pulcherrima) finished under reduced air temperature and bench-top root-zone heating. Sci. Hort 210:197-204.

Runkle, E. and A.J. Both. 2011. Greenhouse energy conservation strategies. Michigan State Univ. Ext. Bul. 3160.

Sachs, R.M., I. Sisto, B.M. Jenkins, and G.W. Forister. 1992. Plant response and energy savings for bench-top-heated greenhouses. Sci. Hort. 49:135-146.

Shedlosky, M.E. and J.W. White. 1987. Growth of bedding plants in response to root-zone heating and night temperature regimes. J. Amer. Soc. Hort. Sci. 112:290-295.

U.S. Department of Agriculture (USDA). 2015a Floriculture crops 2014 summary. Natl. Agr. Stat. Serv., Washington, DC. 30 July 2015.
$<$ http://usda.mannlib.cornell.edu/usda/nass/ FlorCrop//2000s/2001/FlorCrop-04-25-2001.pdf $>$.

U.S. Department of Agriculture (USDA). $2015 \mathrm{~b}$. Census of horticultural specialties (2014). Natl. Agr. Stat. Serv., Washington, DC. 19 Apr. 2015 $<$ http://www.agcensus.usda.gov/Publications/ 2012/Online_Resources/Census_of_Horticulture_ Specialties/HORTIC.pdf $>$.

Vaid, T.M. and E.S. Runkle. 2013. Developing flowering rate models in response to mean temperature for common annual ornamental crops. Sci. Hort. 161:15-23.

Vogelezang, J.V.M. 1988. Effect of root-zone heating on growth, flowering, and keeping quality of Saintpaulia. Sci. Hort. 34:101113.

Vogelezang, J.V.M. 1992. Effect of root-zone and air temperature on flowering and growth of Spathiphyllum and Guzmania minor 'Empire'. Sci. Hort. 49:311-322.

Vogelezang, J.V.M. and P. van Weel. 1989. Bench heating systems and their influence on microclimate. Acta Hort. 245:243-252.

Wai, K.S. and S.E. Newman. 1992. Air and rootzone temperatures influence growth and flowering of snapdragons. HortScience 27:796798.

Warner, R.M. 2010. Temperature and photoperiod influence flowering and morphology of four Petunia spp. HortScience 45:365-368.

Wulster, G.J. and H.W. Janes. 1984. The effect of elevated root zone temperatures of various duration on growth and development of several poinsettia cultivars. Acta Hort. 148:835-842. 